\title{
Sexual dimorphism of sharks from the amazonian equatorial coast
}

\author{
Ana Paula Barbosa Martins ${ }^{1}$, Ednaldo da Silva Filho ${ }^{2}$, Leonardo Manir Feitosa ${ }^{3}$, \\ Luiz Phelipe Nunes e Silva ${ }^{1}$, Zafira da Silva de Almeida ${ }^{4}$, Jorge Luiz Silva Nunes ${ }^{5 \bowtie}$
}

\begin{abstract}
Sexual dimorphism is a widespread feature in several groups of vertebrates. Chondrichthyans differ sexually due to the presence of the clasper, a structure for internal fertilization, and other sexual differences in secondary characteristics. Nevertheless, studies assessing these variations are fairly rare. The main goal of this study is to identify differences in sexual dimorphism in three species of sharks from the Carcharhinidae family (Rhizoprionodon porosus, Carcharbinus porosus and Isogomphodon oxyrbynchus) using morphometric tools. A total of 213 specimens were captured in the Amazonian Equatorial Coast and analyzed using 65 morphometric characters. Discriminant analysis and The Student's t-test were used to demonstrate the morphological differences among sexes. Sexual dimorphism was reported at different levels for the three species. This study suggests that the most likely explanation for the presence of these variations is related to their reproductive characteristics and mating behavior.
\end{abstract}

Keywords: sexual dimorphism; sharks; ecological features; Carcharhinidae

Edited by Alberto Acosta \& Juan Carlos Salcedo-Reyes $\bowtie$

1. Universidade Federal do Maranhão, Programa de Pós-Graduação em Biodiversidade e Conservação, Avenida dos Portugueses 1966, Cidade Universitária do Bacanga, São Luís, Maranhão, Brazil.

2. Universidade Federal Rural da Amazônia, Instituto de Ciências Agrárias, Avenida Presidente Tancredo Neves, Belém-Pará, Brazil.

3. Universidade Federal do Maranhão, Laboratório de Genética e Biologia Molecular, Departamento de Biologia, av. dos Portugueses, S/N, Bacanga -São Luís- Maranhão, Brazil.

4. Universidade Estadual do Maranhão, Laboratório de Pesca e Ecologia Aquática, Cidade Universitária Paulo VI, S/N,

Tirirical -São Luís- Maranhão, Brazil.

5. Universidade Federal do Maranhão, Departamento de Oceanografia e Limnologia, Avenida dos Portugueses 1966, Cidade Universitária do Bacanga, São Luís, Maranhão, Brazil.

Received: 16-09-2014 Accepted: 29-05-2015

Published on line: $18-08-2015$

Citation: Barbosa Martins AP, da Silva Filho E, Manir Feitosa L, Nunes e Silva LP, da Silva de Almeida Z, Silva Nunes JL (2015)

Sexual dimorphism of sharks from the amazonian equatorial coast.

Universitas Scientiarum 20(3): 297-304 doi: 10.11144/Javeriana.SC20-3.sdos

Funding: REVIZEE, CNPq and BASA.

Electronic supplementary material: N/A

\section{Introduction}

Sexual dimorphism is common among vertebrates (Kajiura et al. 2005). With regard to fishes, in mature specimens the internal differences between genders are usually clear, but externally they are not easily differentiated (Moyle \& Cech 2004). Conversely, all cartilaginous fishes exhibit external sexual dimorphism brought about by the modification of males' pelvic fins. This results in a specialized structure for internal fertilization, called clasper. Beyond this evident characteristic, many other species also exhibit sexual dimorphism through other morphological features (Orlov et al. 2010, Orlov \& Cotton 2011).

Males and females of the same species may respond differently to selective pressures (Filiz \& Tasskavak 2006). In the case of elasmobranchs, the differences between males and females include variations in their external reproductive anatomy, 
body size (Compagno 1984, Carlson \& Parsons 1997), dental formula (Kajiura et al. 1996), number and distribution of Ampullae of Lorenzini (Crooks \& Waring 2013a), and dermal thickness (Kajiura et al. 2000, Crooks \& Waring 2013b).These morphological differences can impact ecological aspects such as foraging, competition, and habitat use (Ellis \& Shackley 1995, Piorski \& Nunes 2001). Also, males and females of the same elasmobranch species show different behaviors during mating (Gointein et al. 1998). Nonetheless, these variations in intra-specific secondary sexual characteristics have been poorly studied worldwide (Kajiura 2000, Filiz \& Tasskavak 2006). The Amazonian Equatorial Coast, one of the elasmobranchs conservation hotspots of the world (Dulvy et al. 2014), is no exception.

It is known that Rhizoprionodon porosus and Carcharbinusporosus are the mostabundant elasmobranch catches in Maranhão state (Almeida et al. 2011) and that Isogomphodon oxyrbynchus is an endemic species of the coastal waters off northern South America. These species are listed as critically endangered by the Brazilian government (ICMBIO 2012) but are still captured in some of these areas (Lessa et al. 2006, Rodrigues-Filho et al. 2012). Despite their importance for the local ecosystem and the high fishing economic value in the state, information on the biology and ecology of the shark species of this region is not widely available.

Since updated data about these species is scarce and consistent knowledge is required for developing management strategies for local species, this study aims to evaluate the presence of sexual dimorphism within three Carcharhinidae sharks captured off the coast of Maranhão state, Amazonian Equatorial Coast, Brazil.

\section{Materials and methods}

Area of study: The coastline of Maranhão is the second most extensive in Brazil, with a length of 640 $\mathrm{km}$. The west side of the coastline belongs to the Amazonian Equatorial Coast and is characterized by the presence of recesses with excessively drained river valleys formed by the influence of fluvial estuarine bays (Muehe 2006). As a result, the region has high turbid waters, exuberant mangroves, and rich biotic communities (Souza-Filho 2005) (Figure 1).

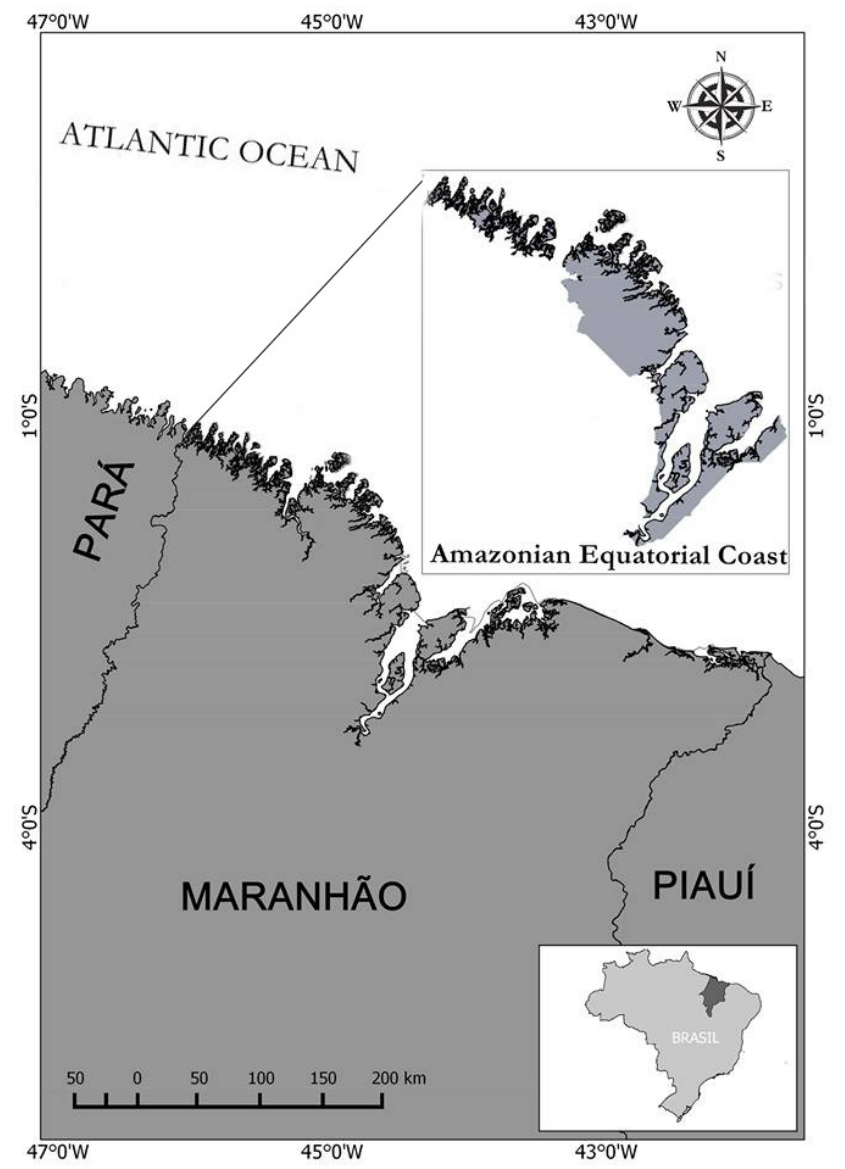

Fig. 1. Map of the coast of Maranhão State, Brazil.

Sampling. morphometric measurements and data analysis: The specimens were caught between October 1997 and March 1999 in shallow waters along the Amazonian Equatorial Coast of Maranhão using gillnets with a mesh size of $95-100 \mathrm{~mm}$. The sharks were stored in thermal coolers with ice and taken to the Ichthyology Laboratory of the Universidade Federal do Maranbão (Federal University of Maranhão) for morphometric analysis. The taxonomic identification was carried out using specialized literature (Compagno 1984).

Using a caliper and metric tape and applying the Piorski et al. (2010) protocol adapted from Compagno (1984), 65 morphometric characteristics were measured in various sized specimens of three shark species: Carcharbinus porosus (50 females with size range: $41.1-89.6 \mathrm{~cm}$ and 20 males with size range: 42.3 - $91.1 \mathrm{~cm}$ ), Rhizoprionodon porosus (11 females with 
size range: $47.6-83.5 \mathrm{~cm}$ and 58 males with size range: $52.3-85.7 \mathrm{~cm}$ ), and Isogomphodon oxyrbynchus (44 females with size range: $40.6-144.0 \mathrm{~cm}$ and 30 males with size range: $70.4-115.0 \mathrm{~cm})($ Table 1$)$.

In order to annul the effect of specimen size, the morphometric measurements were transformed using the Isometric Burnaby method, which projects a series of measured distances within an orthogonal space. The data set was divided into three categories: head, body, and fins. The discriminant analysis (DA) was used to distinguish the differences between sexes in a dependent non-metric variable that characterized the several known classes. Therefore, the objective is to understand the differences between the sexes and predict the probability of an individual belonging

Table 1. Morphometric measures taken from shark species of the Carcharhinidae family caught in the State of Maranhão, Brazil. Ac = Acronyms.

\begin{tabular}{|c|c|c|c|c|c|}
\hline Head measures & Ac & Fin measures & Ac & Body measures & Ac \\
\hline Upper labial fold & ULF & D1 base & D1B & Total length & TL \\
\hline Lower labial fold & LLF & Posterior margin D1 & PMD1 & Fork length & FL \\
\hline Mouth width & MW & Anterior margin D1 & AMD1 & Snout to nostrils & $\mathrm{S} \_\mathrm{N}$ \\
\hline Mouth length & ML & Internal margin D1 & IMD1 & Snout to orbit & S_O \\
\hline Inter-orbital & IO & D1 height & D1H & Snout to mouth & S_M \\
\hline Orbit diameter & OD & Free margin D1 & FMD1 & Snout to $1^{\text {st }}$ gill slits & $\mathrm{S} 1 \mathrm{G}$ \\
\hline Inter-nostril internal distance & INI & D2 base & $\mathrm{D} 2 \mathrm{~B}$ & Snout to $2^{\text {nd }}$ gill slits & S2G \\
\hline \multirow[t]{22}{*}{ Inter-nostril } & IN & Posterior margin D2 & PMD2 & Snout to $3^{\text {rd }}$ gill slits & S3G \\
\hline & & Anterior margin D2 & AMD2 & Snout to $4^{\text {th }}$ gill slits & S4G \\
\hline & & Internal margin D2 & IMD2 & Snout to $5^{\text {th }}$ gill slits & S5G \\
\hline & & D2 height & $\mathrm{D} 2 \mathrm{H}$ & Snout to pectoral fin origin & SP1FO \\
\hline & & Anal base & $\mathrm{AB}$ & Snout to pectoral fin, end of base & SP1FE \\
\hline & & Posterior margin Anal & PMA & Snout to pelvic fin origin & $\mathrm{SP} 2 \mathrm{FO}$ \\
\hline & & Anterior margin Anal & AMA & Snout to $1^{\text {st }}$ dorsal fin origin & SD1FO \\
\hline & & Internal margin Anal & IMA & Snout to $2^{\text {nd }}$ dorsal fin origin & $\mathrm{SD} 2 \mathrm{FO}$ \\
\hline & & Anal height & $\mathrm{AH}$ & Snout to anal fin origin & SAFO \\
\hline & & Pectoral base & PB & Snout to upper caudal fin & SUCF \\
\hline & & Posterior margin P1 & PMP1 & Snout to lower caudal fin & SLCF \\
\hline & & Anterior margin P1 & AMP1 & Inter-dorsal fins & ID \\
\hline & & Internal margin P1 & IMP1 & Pectoral to pelvic fin & PP2 \\
\hline & & Pelvic base & P2B & Pelvic to anal fin & $\mathrm{P} 2 \mathrm{~A}$ \\
\hline & & Posterior margin P2 & PMP2 & $2^{\text {nd }}$ dorsal to anal fin & $\mathrm{D} 2 \mathrm{~A}$ \\
\hline & & Anterior margin P2 & AMP2 & Anal to caudal fin & $\mathrm{AC}$ \\
\hline & & Internal margin $\mathrm{P} 2$ & IMP2 & $1^{\text {st }}$ gill slits length & $1 \mathrm{GL}$ \\
\hline & & Dorsal caudal fin lobe & DCFL & $3^{\text {rd }}$ gill slits length & 3GL \\
\hline & & Ventral caudal fin lobe & VCFL & $5^{\text {th }}$ gill slits length & $5 \mathrm{GL}$ \\
\hline & & Notch of the caudal fin's length & NCFL & Width of the trunk in the pectoral fin origins & WTP1O \\
\hline & & Notch of the caudal fin's depth & NCFD & Height of the trunk in the pectoral fin origins & HTP1O \\
\hline & & & & $1^{\text {st }}$ to $5^{\text {th }}$ gill slits & $1-5 G$ \\
\hline
\end{tabular}


to a particular sex by using the independent metric variables. This analysis was performed using the Paleontological Statistics Software (PAST) Package for education and data analysis, version 3 (Hammer et al. 2001). After normality of the data and homogeneity of the variances were verified, all variables were also tested dichotomously between sexes in order to detect possible sexual dimorphisms, with the Student's t-test considering a significance of 0.05 . This analysis was performed using the program R (R Core Team 2013).

\section{Results and discussion}

A total of 213 specimens were caught in shallow waters of Maranhão state, Amazonian Equatorial Coast. The discriminant analysis for Isogomphodon oxyrbynchus showed no significant difference among the head measurements between sexes, while the measurements of body and fins resulted in discriminant effects $(\mathrm{DA}(\mathrm{HEAD})=$ 0.711, $\mathrm{p}=0.7332, \mathrm{DA}(\mathrm{BODY})=7.57, \mathrm{p}<.0001$, $\mathrm{DA}(\mathrm{FINS})=16.124, \mathrm{p}<.0001)$. This species showed

Table 2. Results of t-student test for Rhizoprionodon porosus and Carcharbinus porosus. F - Female, M - Male, SD - standard deviation, $\mathrm{T}$ - $\mathrm{t}$-test result and $\mathrm{p}-\mathrm{p}$-value (considered significant if $\mathrm{p}<0.05$ ).

\begin{tabular}{|c|c|c|c|c|c|c|c|c|c|c|c|c|c|c|}
\hline $\begin{array}{c}R . \\
\text { porosus }\end{array}$ & Variable & $\mathrm{F}$ & SD & M & SD & $\mathrm{T}$ & $\mathrm{p}$ & Variable & $\mathrm{F}$ & SD & M & SD & $\mathrm{T}$ & $\mathrm{p}$ \\
\hline & ULF & 1.276 & \pm 0.183 & 1.610 & \pm 0.277 & -3.75 & 0.0005 & 3GL & 1.467 & \pm 0.103 & 2.002 & \pm 0.278 & -4.62 & $<.0001$ \\
\hline & LLF & 0.817 & \pm 0.098 & 1.121 & \pm 0.176 & -4.12 & 0.002 & $5 \mathrm{GL}$ & 1.067 & \pm 0.051 & 1.545 & \pm 0.308 & -3.76 & $<.0001$ \\
\hline & MW & 3.100 & \pm 0.253 & 4.200 & \pm 0.679 & -3.90 & 0.0003 & D1B & 5.250 & \pm 0.207 & 6.493 & \pm 0.697 & -4.30 & $<.0001$ \\
\hline & ML & 4.017 & \pm 0.495 & 5.441 & \pm 0.741 & -4.54 & $<.0001$ & PMD1 & 5.450 & \pm 0.301 & 6.524 & \pm 1.028 & -2.52 & $<.0001$ \\
\hline & $\mathrm{IO}$ & 4.800 & \pm 0.456 & 6.619 & \pm 0.746 & -5.79 & $<.0001$ & AMD1 & 6.483 & \pm 0.479 & 8.000 & \pm 0.755 & -4.76 & $<.0001$ \\
\hline & IN & 2.850 & \pm 0.242 & 3.750 & \pm 0.375 & -5.67 & $<.0001$ & D1H & 5.417 & \pm 0.360 & 6.112 & \pm 0.498 & -3.28 & 0.0020 \\
\hline & S_N & 2.817 & \pm 0.348 & 3.671 & \pm 0.390 & -5.07 & $<.0001$ & D2B & 1.633 & \pm 0.280 & 2.088 & \pm 0.230 & -4.40 & $<.0001$ \\
\hline & S_O & 4.817 & \pm 0.213 & 5.912 & \pm 0.526 & -5.00 & $<.0001$ & PMD2 & 2.783 & \pm 0.040 & 3.626 & \pm 0.400 & -5.10 & $<.0001$ \\
\hline & S_B & 4.550 & \pm 0.197 & 5.536 & \pm 0.488 & -4.85 & $<.0001$ & AMD2 & 1.900 & \pm 0.400 & 2.205 & \pm 0.223 & -2.81 & 0.0072 \\
\hline & $\mathrm{S} 1 \mathrm{G}$ & 10.450 & \pm 0.595 & 13.486 & \pm 1.480 & -4.93 & $<.0001$ & IMD2 & 2.433 & \pm 0.413 & 3.188 & \pm 0.339 & -4.97 & $<.0001$ \\
\hline & S2G & 10.983 & \pm 0.577 & 14.188 & \pm 1.544 & -4.99 & $<.0001$ & D2H & 1.317 & \pm 0.183 & 1.710 & \pm 0.309 & -3.02 & 0.0041 \\
\hline & $\mathrm{S} 3 \mathrm{G}$ & 11.567 & \pm 0.575 & 14.945 & \pm 1.644 & -4.95 & $<.0001$ & $\mathrm{AB}$ & 2.717 & \pm 0.098 & 3.229 & \pm 0.407 & -3.04 & $<.0001$ \\
\hline & $\mathrm{S} 4 \mathrm{G}$ & 12.117 & \pm 0.624 & 15.648 & \pm 1.687 & -5.04 & $<.0001$ & PMA & 3.167 & \pm 0.121 & 3.843 & \pm 0.419 & -3.90 & $<.0001$ \\
\hline & S5G & 12.583 & \pm 0.624 & 15.017 & \pm 1.878 & -4.41 & $<.0001$ & AMA & 2.400 & \pm 0.328 & 2.929 & \pm 0.269 & -4.37 & $<.0001$ \\
\hline & SP1FE & 14.283 & \pm 0.682 & 18.000 & \pm 1.969 & -4.55 & $<.0001$ & $\mathrm{AH}$ & 1.783 & \pm 0.229 & 2.045 & \pm 0.288 & -2.13 & 0.0386 \\
\hline & $\mathrm{SP} 2 \mathrm{FO}$ & 25.850 & \pm 1.893 & 32.712 & \pm 3.224 & -5.06 & $<.0001$ & PB & 3.233 & \pm 0.287 & 3.881 & \pm 0.422 & -3.62 & $<.0001$ \\
\hline & SD1FO & 17.133 & \pm 0.880 & 22.252 & \pm 2.366 & -5.21 & $<.0001$ & PMP1 & 5.183 & \pm 0.895 & 6.636 & \pm 0.626 & -5.04 & $<.0001$ \\
\hline & $\mathrm{SD} 2 \mathrm{FO}$ & 35.633 & \pm 1.894 & 45.890 & \pm 6.723 & -3.68 & $<.0001$ & AMP1 & 7.283 & \pm 0.457 & 9.248 & \pm 0.950 & -4.94 & $<.0001$ \\
\hline & SAFO & 34.050 & \pm 1.923 & 44.798 & \pm 4.512 & -5.72 & $<.0001$ & IMP1 & 2.567 & \pm 0.051 & 3.036 & \pm 0.304 & -3.73 & 0.0005 \\
\hline & SUCF & 41.817 & \pm 2.487 & 55.086 & \pm 6.369 & -5.01 & $<.0001$ & P2B & 2.650 & \pm 0.207 & 3.293 & \pm 0.343 & -4.44 & $<.0001$ \\
\hline & SLCF & 41.067 & \pm 2.631 & 54.350 & \pm 6.174 & -5.16 & $<.0001$ & PMP2 & 2.450 & \pm 0.137 & 2.898 & \pm 0.322 & -3.34 & 0.0017 \\
\hline & ID & 13.733 & \pm 0.833 & 18.462 & \pm 2.048 & -5.55 & $<.0001$ & AMP2 & 2.633 & \pm 0.206 & 3.393 & \pm 0.389 & -4.66 & $<.0001$ \\
\hline & PP2 & 12.533 & \pm 1.506 & 15.831 & \pm 1.560 & -4.86 & $<.0001$ & IMP2 & 3.133 & \pm 0.216 & 2.279 & \pm 0.325 & 6.22 & $<.0001$ \\
\hline & $\mathrm{P} 2 \mathrm{~A}$ & 6.450 & \pm 1.459 & 8.983 & \pm 1.156 & -4.87 & $<.0001$ & DCFL & 15.500 & \pm 0.784 & 18.01 & \pm 2.350 & -2.57 & 0.0134 \\
\hline & $\mathrm{D} 2 \mathrm{~A}$ & 4.767 & \pm 0.680 & 6.210 & \pm 0.687 & -4.81 & $<.0001$ & VCFL & 6.583 & \pm 0.778 & 8.157 & \pm 0.580 & -5.96 & $<.0001$ \\
\hline & $\mathrm{AC}$ & 4.967 & \pm 0.582 & 6.355 & \pm 0.713 & -4.54 & $<.0001$ & NCFD & 1.750 & \pm 0.083 & 1.917 & \pm 0.139 & -2.84 & 0.0067 \\
\hline & $1 \mathrm{GL}$ & 1.083 & \pm 0.040 & 1.479 & \pm 0.190 & -5.02 & $<.0001$ & & & & & & & \\
\hline
\end{tabular}


only three significant variations (Paired t test, $\mathrm{tP} 2 \mathrm{~A}=$ -3.47, $\mathrm{p}=0.0009 ;$ tPMP2 $=2.29, \mathrm{p}=0.0253$; tIMP2 $=9.07, \mathrm{p}<0.0001)$ in the t-test analysis conducted for each of the 65 morphometric measurements.

Distinctions between sexes for the Rhizoprionodon porosus were identified by all the discriminant analysis. Significant head, body, and fin measurements were obtained $(\mathrm{DA}(\mathrm{HEAD})=3.641, \mathrm{p}=0.0013$, $\mathrm{DA}(\mathrm{BODY})=3.509, \mathrm{p}=0.0036, \mathrm{DA}(\mathrm{FINS})=68.176$, $\mathrm{p}<.0001)$. The t-test result identified 53 significantly distinct morphometric measurements among males and females (Table 2). Concerning Carcharbinus porosus, only the head measurements were statistically significant in the discriminant analysis, while the measures of body and fins were not $(\mathrm{DA}(\mathrm{HEAD})=3.578, \mathrm{p}=0.0091$, $\mathrm{DA}(\mathrm{BODY})=1.319, \mathrm{p}=0.3726, \mathrm{DA}(\mathrm{FINS})=1.975$, $\mathrm{p}=0.5174)$. The $\mathrm{t}$-test showed 54 morphometric measurements significantly different between males and females (Table 2).

\begin{tabular}{|c|c|c|c|c|c|c|c|c|c|c|c|c|c|c|}
\hline $\begin{array}{c}C . \\
\text { porosus }\end{array}$ & Variable & $\mathrm{F}$ & SD & $\mathbf{M}$ & SD & $\mathrm{T}$ & $\mathrm{p}$ & Variable & $\mathrm{F}$ & SD & $\mathbf{M}$ & $\mathrm{SD}$ & $\mathrm{T}$ & $\mathrm{p}$ \\
\hline & SLS & 0.300 & \pm 0.081 & 0.200 & \pm 0.077 & 3.29 & 0.0027 & $5 \mathrm{GL}$ & 1.695 & \pm 0.297 & 1.391 & \pm 0.144 & 3.16 & 0.0037 \\
\hline & MW & 4.063 & \pm 0.501 & 3.118 & \pm 0.543 & 4.83 & $<.0001$ & D1B & 6.900 & \pm 0.952 & 5.346 & \pm 0.621 & 4.83 & $<.0001$ \\
\hline & ML & 5.442 & \pm 0.683 & 4.182 & \pm 0.485 & 5.37 & $<.0001$ & PMD1 & 7.558 & \pm 1.186 & 5.546 & \pm 0.747 & 5.06 & $<.0001$ \\
\hline & $\mathrm{IO}$ & 6.353 & \pm 0.931 & 4.946 & \pm 0.965 & 3.93 & 0.0005 & AMD1 & 7.979 & \pm 1.208 & 6.182 & \pm 0.702 & 4.49 & 0.0001 \\
\hline & IN & 3.468 & \pm 0.400 & 2.682 & \pm 0.651 & 4.12 & 0.0003 & FMD1 & 3.537 & \pm 0.450 & 2.455 & \pm 0.317 & 7.01 & $<.0001$ \\
\hline & S_N & 3.821 & \pm 0.369 & 3.082 & \pm 0.312 & 5.58 & $<.0001$ & $\mathrm{D} 1 \mathrm{H}$ & 6.253 & \pm 1.053 & 4.573 & \pm 0.703 & 4.70 & $<.0001$ \\
\hline & S_O & 6.100 & \pm 0.597 & 4.882 & \pm 0.666 & 5.16 & $<.0001$ & $\mathrm{D} 2 \mathrm{~B}$ & 2.258 & \pm 0.403 & 1.846 & \pm 0.206 & 3.15 & 0.0039 \\
\hline & S_B & 5.151 & \pm 0.539 & 4.718 & \pm 0.599 & 3.72 & 0.0009 & PMD2 & 3.074 & \pm 0.506 & 2.373 & \pm 0.431 & 3.85 & 0.0006 \\
\hline & $\mathrm{S} 1 \mathrm{G}$ & 17.911 & \pm 2.213 & 14.645 & \pm 1.427 & 4.38 & 0.0002 & IMD2 & 2.737 & \pm 0.321 & 2.027 & \pm 0.195 & 6.61 & $<.0001$ \\
\hline & S2G & 13.611 & \pm 1.600 & 11.100 & \pm 1.097 & 4.58 & $<.0001$ & $\mathrm{D} 2 \mathrm{H}$ & 1.753 & \pm 0.412 & 1.273 & \pm 0.190 & 3.62 & 0.0012 \\
\hline & S3G & 14.363 & \pm 1.710 & 11.700 & \pm 1.192 & 4.55 & $<.0001$ & $\mathrm{AB}$ & 2.879 & \pm 0.404 & 2.218 & \pm 0.240 & 4.91 & $<.0001$ \\
\hline & S4G & 15.047 & \pm 1.750 & 12.282 & \pm 1.226 & 4.61 & $<.0001$ & PMA & 2.790 & \pm 0.546 & 2.146 & \pm 0.344 & 3.51 & 0.0015 \\
\hline & S5G & 15.721 & \pm 1.808 & 12.900 & \pm 1.253 & 4.56 & $<.0001$ & AMA & 3.442 & \pm 0.567 & 2.773 & \pm 0.337 & 3.55 & 0.0014 \\
\hline & SP1FO & 14.389 & \pm 1.938 & 12.100 & \pm 1.141 & 3.56 & 0.0013 & IMA & 2.642 & \pm 0.365 & 1.973 & \pm 0.214 & 5.52 & $<.0001$ \\
\hline & SP1FE & 17.911 & \pm 2.213 & 14.645 & \pm 1.427 & 4.38 & 0.0002 & $\mathrm{AH}$ & 2.247 & \pm 0.453 & 1.573 & \pm 0.214 & 4.61 & $<.0001$ \\
\hline & $\mathrm{SP} 2 \mathrm{FO}$ & 30.674 & \pm 4.610 & 24.209 & \pm 2.364 & 4.3 & 0.0002 & PB & 4.190 & \pm 0.628 & 3.303 & \pm 0.234 & 5.27 & $<.0001$ \\
\hline & SD1FO & 19.711 & \pm 2.360 & 16.455 & \pm 1.496 & 4.11 & 0.0003 & PMP1 & 8.105 & \pm 1.425 & 5.755 & \pm 0.759 & 5.05 & $<.0001$ \\
\hline & $\mathrm{SD} 2 \mathrm{FO}$ & 40.400 & \pm 6.231 & 32.300 & \pm 3.323 & 3.98 & 0.0004 & AMP1 & 9.221 & \pm 2.290 & 7.400 & \pm 0.883 & 2.52 & 0.0179 \\
\hline & SAFO & 39.000 & \pm 6.001 & 31.218 & \pm 3.212 & 3.96 & 0.0005 & IMP1 & 3.447 & \pm 0.545 & 2.709 & \pm 0.298 & 4.13 & 0.0003 \\
\hline & SUCF & 46.763 & \pm 6.045 & 38.073 & \pm 3.921 & 4.26 & 0.0002 & P2B & 3.205 & \pm 0.458 & 2.436 & \pm 0.459 & 4.42 & 0.0001 \\
\hline & SLCF & 45.558 & \pm 5.952 & 37.145 & \pm 3.872 & 4.19 & 0.0003 & PMP2 & 3.253 & \pm 0.489 & 3.436 & \pm 0.528 & 3.85 & 0.0006 \\
\hline & ID & 14.458 & \pm 1.993 & 11.573 & \pm 1.358 & 4.25 & 0.0002 & AMP2 & 3.663 & \pm 0.409 & 2.736 & \pm 0.429 & 5.87 & $<.0001$ \\
\hline & PP2 & 13.053 & \pm 1.961 & 10.673 & \pm 1.149 & 3.66 & 0.0010 & IMP2 & 3.984 & \pm 0.600 & 1.709 & \pm 0.661 & 9.64 & $<.0001$ \\
\hline & $\mathrm{D} 2 \mathrm{~A}$ & 4.726 & \pm 0.688 & 4.109 & \pm 0.568 & 2.51 & 0.018 & DCFL & 15.800 & \pm 1.958 & 12.99 & \pm 1.497 & 4.10 & 0.0003 \\
\hline & $\mathrm{AC}$ & 4.942 & \pm 0.708 & 4.191 & \pm 0.678 & 2.84 & 0.083 & VCFL & 7.726 & \pm 1.192 & 6.218 & \pm 0.625 & 3.88 & 0.0006 \\
\hline & $1 \mathrm{GL}$ & 1.503 & \pm 0.339 & 1.227 & \pm 0.161 & 2.54 & 0.0168 & ANCFL & 4.500 & \pm 0.785 & 3.491 & \pm 0.493 & 3.83 & 0.0007 \\
\hline & 3GL & 2.068 & \pm 0.351 & 1.627 & \pm 0.190 & 3.83 & 0.0007 & NCFD & 2.258 & \pm 0.285 & 1.864 & \pm 0.283 & 3.65 & 0.0011 \\
\hline
\end{tabular}


The presence and absence of variations found in the three species could be related to different factors. According to Navarro et al. (2013) foraging specialization occurs between sexes within marine predators, including sharks. This could result in the development of distinctive features for each sex, which can arise in response to an increase in the competition for food resources (Wearmouth \& Sims 2008). However, we discard this factor for two reasons: (1) I. oxyrbynchus showed no differences in head measurements, the area most related to this process. This suggests that if differences in dietary habits existed, they were not sufficient to derive any morphological variations among sexes of this species; (2) The several studies that have evaluated feeding habits in Maranhão's coast have not found any sexually dimorphic diets for these three species (Lessa \& Almeida 1997, Lessa et al. 1999, Silva \& Almeida 2001, Almeida et al. 2011).

Another factor related to sexual dimorphism is body size. Sexual dimorphism expressed in body size is common among viviparous and ovoviviparous shark species (Sims 2003). According to Lessa et al. (2000), Machado et al. (2000), and Santos et al. (2000) females of the three species studied, as the vast majority of shark species, tend to be larger than males. This is the case for I. oxyrbynchus and R. porosus, whose differences in body size can be related to the reproductive pattern of shark females. Females have larger energy expenditure than males due to the selection pressure for large offspring (Sims 2003). Additionally, males and females may present different growth rates as juveniles, which directly influences body size (Lessa et al. 2000). This hypothesis was also discarded given that the results were presented with the size effects standardized, preventing the size of the individuals from influencing the results.

In the present study, fin measurements for $R$. porosus and I. oxyrbynchus showed significant variations. Likewise, head measurements for R. porosus and C. porosus also demonstrated significant values. Due to the lack of documented ecological data for these species it is hard to assess the more likely cause for these results. It is hypothesized that the distinction of head and fins may be related to reproductive behavior. According to Crooks \& Waring (2013a) sharks usually display a complex pattern of reproductive behavior in which the male has to bite one of the female's fins to enable copulation. The differences found may suggest adaptations of the male's head to bite and of the female's fins to receive these bites.

The t-test results for males and females of $R$. porosus and C. porosus showed the same morphological patterns. According to Lessa (1997), these species are very similar morphologically, which makes it difficult to distinguish Them taxonomically, thus explaining these similar results. The t-test result for I. oxyrbynchus was significant only for the pelvic area and may be related to the parturition and copulation processes. All three species analyzed were viviparous, and therefore had the same pelvic measurements with statistically significant values. as expected due to the known sexual dimorphism in primary characters of sharks.

\section{Conclusion}

A possible cause for the variations in the external morphology among males and females of I. oxyrbynchus, $\mathrm{R}$. porosus and C. porosus is their reproductive patterns. It is clear that in order to further elucidate and test this hypothesis, further research on reproductive and behavioral features for each species must be carried out. This study revealed important details about the sexual dimorphism of Isogomphodon oxyrbynchus, Rhizoprionodon porosus and Carcharbinus porosus through morphometric analysis, and will help facilitate the development of future studies in the area.

\section{Acknowledgements}

We would like to thank REVIZEE, CNPq, and BASA for the financial support and Universidade Federal do Maranbão for the logistical support.

\section{Conflicts of interest}

The authors certify that there are no conflicts of interest related to Individual Authors' Commitments, Project Support, Commitments of Editors, Journal Staff, or Reviewers. The authors also certify that they have NO affiliations with or involvement in any organization or entity with any financial interest or non-financial interest in the subject matter or materials discussed in this manuscript. 


\section{References}

Almeida ZS, Frédou FL, Nunes JLS, Lessa RP, Pinheiro ALR (2011) Biodiversidade de elasmobrânquios. In: Nunes JLS \& Piorski NM (eds) Peixes marinhos e estuarinos do Maranhão. Editora Café e Lápis, Brasil, pp 37-94

Carlson J K, Parsons GR (1997) Age and growth of the bonnethead sharks, Sphyrna tiburo, from northwest Florida, with comments on clinal variation. Environmental Biology of Fishes 50:331-341

Compagno LJV (1984) FAO species catalogue: Sharks of the world, an annotated and illustrated catalogue of shark species known to date. FAO Fisheries Synopsis 125(4) Part 2:251-655

Crooks N, Waring CP (2013a) A study into the sexual dimorphisms of the Ampullae of Lorenzini in the lesser-spotted catshark, Scyliorbinus canicula (Linnaeus, 1758). Environmental Biology of Fishes 96:585-590 doi: 10.1007/s10641-012-0048-8

Crooks N, Waring CP (2013b) Sexual dimorphisms in the dermal structure of the lesser-spotted catshark, Scyliorbinus canicula (Linnaeus, 1758). Acta Zoologica 94:331-334 doi: 10.1111/j.1463-6395.2012.00560.x

Dulvy NK, Fowler SL, Musick JA, Cavanagh RD, Kyne PM et al. (2014) Extinction risk and conservation of the world's sharks and rays. eLife3:e00590 doi: 10.7554/ eLife.00590.001

Ellis JR, Shackley SE (1995) Onthogenetic changes and sexual dimorphism and the head, mouth and teeth of the lesser spotted dogfish. Journal of Fish Biology 47(1):155-164

Filiz H, Taşkavak E (2006) Sexual dimorphism in the head, mouth, and body morphology of the smallspotted catshark, Scyliorbinus canicula (Linnaeus, 1758) (Chondrichthyes: Scyliorhinidae) from Turkey. Acta Adriatica 47(1):37-47

Gointein R, Torres FS, Signorini CE (1998) Morphological aspects related to feeding of two marine skates Narcine brasiliensis Olfers and Rhinobatos horkelli Muller \& Henle. Acta Scientiarum 20(2):165-169

Hammer O, Harper DAT, Ryan PD (2001) PAST: Paleontological Statistics Software Package for Education and Data Analysis http://palaeoelectronica. org/2001_1/past/issue1_01.htm. Retrieved November 122014

ICMBIO 2012. Avaliação Científica do Risco de Extinção da Fauna Brasileira - Resultados Alcançados em 2012

Kajiura SM, Tricas TC (1996) Seasonal dynamics of dental sexual dimorphism in the Atlantic stingray, Dasyatis sabina. Journal of Experimental Biology 199:2297-2306
Kajiura SM, Sebastian AP, Tricas TC (2000) Dermal bite wounds as indicators of reproductive seasonality and behaviour in the Atlantic stingray, Dasyatis sabina. Environmental Biology of Fishes 58:23-31

Kajiura SM, Tyminski JP, Forni JB, Summers AP (2005) The Sexually Dimorphic Cephalofoil of Bonnethead Sharks, Sphyrna tiburo. Biological Bulletin 209:1-5

Lessa RP (1997) Sinopse dos estudos sobre elasmobrânquios da costa do Maranhão. Boletim do Laboratório de Hidrobiologia 10:19-36

Lessa RP, Almeida ZS (1997) Analysis of stomach contents of the small tail shark, Carcharbinus porosus, from northern Brazil. Cybium 21(2):123-133

Lessa RP, Santana FM (1998) Age determination and growth of the small tail shark, Carcharbinus porosus, from northern Brazil. Marine and Freshwater Research 49:705-11

Lessa RP, Batista V, Almeida ZS (1999) Occurrence and biology of the daggernose shark Isogomphodon oxyrbynchus (Chondrichthyes: Carcharhinidae) off the Maranhão coast (Brazil). Bulletin of Marine Science 64(1):115-128

Lessa RP, Santana FM, Batista V, Almeida ZS (2000) Age and growth of the daggernose shark, Isogomphodon oxyrbynchus, from northern Brazil. Marine and Freshwater Research 51:339-47

Lessa RP, Charvet-Almeida P, Santana FM, Almeida ZS (2006) Isogomphodon oxyrbynchus. The IUCN Red List of Threatened Species Version 2014.2. www.iucnredlist. org. Retrieved August 312014

Machado MRB, Almeida ZS, Castro ACL (2000) Estudo da biologia reprodutiva de Rhizoprionodon porosus Poey 1861 (Pisces - Elasmobranchii - Carcarhinidae) na plataforma continental do estado do Maranhão, Brasil. Boletim do Laboratório de Hidrobiologia 13: 51-65

Moyle PB, Cech J J (2004). Fishes: an introduction to ichthyology. Upper Saddle River, NJ: Pearson Prentice Hall, 726 p.

Muehe D (2006) Erosão e Progradação do Litoral Brasileiro. Ministério do Meio Ambiente, D.F., Brasil.

Navarro J, Coll M, Preminger M, Palomera I (2013) Feeding ecology and trophic position of a Mediterranean endemic ray: consistency between sexes, maturity stages and seasons. Environmental Biology of Fishes 96:13151328 doi: 10.1007/s10641-013-0109-7

Orlov AM, Cotton CF, Shevernitsky DA (2010) Sexual Dimorphism of External Morphological Characters in Some Deepwater Skates (Rajidae, Rajiformes, Chondrichthyes) of the North Atlantic. Moscow University Biological Sciences Bulletin 65(1):40-44 doi: 10.3103/S0096392510010086 
Orlov AM, Cotton CF (2011) Sexually dimorphic morphological characters in five north Atlantic deepwater skates (Chondrichthyes: Rajiformes). Journal of Marine Biology 2011:1-18 doi: 10.1155/2011/842821

Piorski NM, Nunes JLS (2001) Dimorfismo sexual e tendência alométrica de Urotrygon microphthalmum Deslman, 1941 (Elasmobranchii: Urolophidae). Boletim do Laboratório de Hidrobiologia 13:67-81

R Core Team (2013) R: A language and environment for statistical computing. R Foundation for Statistical Computing

Rodrigues-Filho LF, Pinhal D, Sodré D, Vallinoto M (2012) Shark DNA Forensics: Applications and Impacts on Genetic Diversity. Analysis of Genetic Variation in Animals 269-286

Santos CRC, Almeida ZS, Castro ACL, Machado MRB (2000) Biologia reprodutiva de Carcharbinus porosus Razani 1839 (Condrichthyes, Elasmobranchii) em águas rasas maranhenses. Boletim do Laboratório de Hidrobiologia $12: 49-63$

\section{Dimorfismo sexual de tiburones de la costa ecuatorial} amazónica

Resumen. El dimorfismo sexual es una característica presente en diversos grupos de vertebrados. Machos y hembras de Chondrichthyes se identifican fácilmente por la presencia de una estructura para la fertilización interna, el clasper, y otras pequeñas diferencias en las características secundarias. Sin embargo, los estudios que evalúan estas variaciones en la morfología entre los sexos son poco frecuentes. El objetivo de este trabajo es identificar el dimorfismo sexual en tres especies de tiburones de la familia Carcharhinidae (Rhizoprionodon porosus, Carcharbinus porosus y Isogomphodon oxyrbynchus) con el uso de herramientas morfométricas. Se capturaron un total de 213 ejemplares en la costa Ecuatorial Amazónica y fueran analizados utilizando 65 caracteres morfométricos. Fueran aplicadas análisis discriminantes y prueba t-student para mostrar las diferencias morfológicas entre los sexos. Se observó dimorfismo sexual en diferentes niveles para las tres especies. Sugerimos que la explicación más probable para la presencia de estas variaciones está relacionada con las características reproductivas y el comportamiento de cópula.

Palabras clave: dimorfismo sexual, tiburones, aspectos ecológicos; Carcharhinidae
Silva CML, Almeida ZS (2001) Alimentação de Rbizoprionodon porosus (Elasmobranchii: Carcharhinidae) da costa do Maranhão, Brasil. Boletim do Instituto de Pesca 27(2):201-207

Sims DW (2003) Tractable models for testing theories about natural strategies: foraging behaviour and habitat selection of free-ranging sharks. Journal of Fish Biology 63(A):53-73

Souza Filho PWM (2005) Costa de manguezais de macromaré da Amazônia: Cenários morfológicos, mapeamento e quantificação de áreas usando dados de sensores remotos. Revista Brasileira de Geofísica 23(4):427435

Wearmouth VJ, Sims DW (2008) Sexual segregation in marine fish, reptiles, birds and mammals behaviour patterns, mechanisms and conservation implications. Advances in Marine Biology 54:107-70 doi: 10.1016/ S0065-2881(08)00002-3

Dimorfismo sexual de tubaróes da costa equatorial amazônica

Resumo. O dimorfismo sexual é uma característica presente em vários grupos de vertebrados. Machos e fêmeas de Chondrichthyes são facilmente identificados pela presença de uma estrutura para a fertilização interna, o clasper, além de outras diferenças em características secundárias. No entanto, estudos que avaliam estas variações na morfologia externa entre os sexos são raros. $\mathrm{O}$ principal objetivo deste estudo é identificar dimorfismo sexual em três espécies de tubarão da família Carcharhinidae (Rhizoprionodon porosus, Carcharbinus porosus e Isogomphodon oxyrbynchus) através do uso de ferramentas morfométricas. Um total de 213 espécimes foi capturado na costa Equatorial Amazônica e analisado através de 65 caracteres morfométricos. Análises discriminantes e teste t-student foram aplicados para evidenciar as diferenças morfológicas entre os sexos. Nós observamos dimorfismo sexual, em diferentes níveis, para as três espécies estudadas e sugerimos que a causa mais provável para a presença de tais variações está relacionada a características reprodutivas e comportamentos copulatórios.

Palavras-chave: dimorfismo sexual, tubarões, aspectos ecológicos, Carcharhinidae 